Gut, 1982, 23, 545-551

Clinical trial

\title{
Comparison between cimetidine and Caved-S in the treatment of gastric ulceration, and subsequent maintenance therapy
}

\author{
A G MORGAN, * W A F McADAM, C PACSOO, and A DARNBOROUGH \\ From the Endoscopy Unit and Department of Radiology, Airedale General Hospital, Steeton, Keighley, West \\ Yorkshire
}

SUMMARY One hundred patients with benign gastric ulceration were treated in a single-blind, endoscopically controlled trial to assess the relative efficacy of cimetidine ( $1 \mathrm{~g}$ daily) and Caved-S (six tablets daily). Ulcer healing was assessed after six weeks' treatment, and, if incomplete, after a further six weeks. There was no significant difference between the two drug regimens (approximately 63\% at six weeks and $91 \%$ at 12 weeks). If an ulcer remains unhealed after 12 weeks' treatment the patient should undergo surgery. There was no difference in the relief of day pain between the two drug regimens but cimetidine was more effective over the first two weeks of treatment in relieving night pain, than was Caved-S $(\mathrm{p}<0.02)$. After ulcer healing, drug dosage was reduced (cimetidine to $400 \mathrm{mg}$ at night and Caved-S to two tablets twice daily). So far, 56 patients, 28 in each group, have completed the first year's maintenance treatment, and there have been four ulcer recurrences in each group (14\%).

Carbenoxolone until comparatively recently was the drug of choice for the treatment of gastric ulceration. ${ }^{1}$ In 1978 we published the results of a study ${ }^{2}$ in which patients under the age of 60 years were treated with either cimetidine or carbenoxolone and those over 60 with cimetidine or Caved-S. Cimetidine was found to be more effective than carbenoxolone. The healing rates for Caved-S and cimetidine were similar. Caved-S contains deglycyrrhizinated liquorice and thus has none of the potential side-effects of carbenoxolone ${ }^{3}$ (fluid retention, congestive heart failure, hypokalaemia, and hypertension).

Following this study, we decided that, before Caved-S could be unreservedly recommended for the treatment of gastric ulceration, a further trial was required, this time incorporating larger treatment groups and patients of all ages. The results of this trial form the basis of this paper.

\footnotetext{
* Address for reprint requests: Dr A G Morgan, Airedale General Hospital, Steeton, Keighley, West Yorkshire BD20 6TD.

Received for publication 2 November 1981
}

\section{Methods}

\section{PATIENT SELECTION}

An attempt has been made to include all patients presenting either to the Department of Radiology or the Endoscopic Unit with gastric ulceration (prepyloric ulcers excluded). The hospital alone provides acute services for a population of approximately 160000 , a completely unselected group of patients was thus entered into the study.

\section{HEALING STUDY}

Drug treatment and dosage

The nature of the trial was fully explained to the patients before entry and their informed consent obtained in accordance with the Declaration of Helsinki. They were then randomly allocated (single-blind) to treatment with either Caved-S, deglycyrrhizinated liquorice plus antacid combination, two tablets to be chewed three times a day between meals or cimetidine $200 \mathrm{mg}$ three times a day and $400 \mathrm{mg}$ at night. All patients were given antacids (Rennies) to take as required. A personal diary card was completed recording severity of 
symptoms, the number of antacids taken, and drug compliance. Treatment was continued for up to 12 weeks.

\section{Method for random allocation}

The choice of treatment for each patient was determined using tables of random numbers. The chosen regimen was then placed in sealed envelopes numbered one to 100 by a colleague not involved in the study.

\section{Initial investigations and follow-up}

Endoscopy was performed on all patients at the start of the study and after six weeks' treatment. If healing was incomplete, a further six weeks' treatment was prescribed and endoscopy repeated after a total of 12 weeks' therapy. All ulcers were biopsied to exclude an ulcer cancer. Ulcer healing was defined as complete disappearance of ulceration or erosion. Ulcer size was usually assessed using an ACMI endoscopic measuring gauge or the open biopsy forceps. Treatment was considered to have failed when an ulcer remained unhealed after three months' treatment or the patient was withdrawn from the trial because of complications or failure to control symptoms.

A safety screening programme, including haematological, biochemical, and clinical parameters, was carried out at the time of each endoscopy.

\section{MAINTENANCE STUDY}

Once ulcer healing had been achieved, all those patients who were fit enough were entered into a two year maintenance study. The dose of cimetidine was reduced to $400 \mathrm{mg}$ at night and that of Caved-S to two tablets twice a day. All patients were reviewed in the outpatient department at three monthly intervals and the safety screening programme was repeated at six monthly intervals. The patients and general practitioners were asked to report any recurrence of dyspeptic symptoms between outpatient visits, so that endoscopy could be done within a few days to check for a possible ulcer recurrence. After six months' maintenance therapy, a routine barium meal examination was performed to seek an asymptomatic ulcer recurrence.

\section{Statistical methods}

The chi square test was used for groups with large numbers, and the binomial test for small numbers. The pain score data were analysed after logarithmic transformation and the regression coefficients compared using Student's $t$ test on pairs of the mean value.

\section{Results}

\section{HEALING STUDY}

The treatment groups were evenly matched for all parameters analysed (Table 1). There was no statistical difference in the healing rates for the two drug regimens. Approximately $63 \%$ of all ulcers were healed at six weeks and $91 \%$ after 12 weeks' treatment (Table 2). No patients experienced any important side-effects, but the safety screening picked up two patients on cimetidine who developed a transient rise in serum transaminase (maximum ALT of 76 and $50 \mathrm{IU} / 1$, respectively, normal range up to $36 \mathrm{IU} / 1)$.

Diary cards were completed in 32 out of 50 patients in the Caved-S group and 26 out of 50 in the cimetidine group. The consumption of Rennies tablets was small. Severity of symptoms was scored as follows: no pain -0 , mild pain -1 , moderate pain

Table 1 Comparability of two treatment groups

\begin{tabular}{|c|c|c|}
\hline & Caved-S & Cimetidine \\
\hline \multicolumn{3}{|l|}{ Age (yr) } \\
\hline Mean (SD) & $62 \pm 12$ & $62 \pm 14$ \\
\hline \multicolumn{3}{|l|}{ Sex } \\
\hline Male & 17 & 19 \\
\hline Female & 33 & 31 \\
\hline \multicolumn{3}{|l|}{ Length of history } \\
\hline$<6$ months & 20 & 21 \\
\hline 6 months to 5 years & 13 & 14 \\
\hline 5 years + & 17 & 15 \\
\hline \multicolumn{3}{|l|}{ Cigarette smokers } \\
\hline Yes ( $>10$ per day) & 22 & 21 \\
\hline No & 23 & 21 \\
\hline \multicolumn{3}{|l|}{ Alcohol consumption } \\
\hline Nil & 21 & 27 \\
\hline$<10$ pints per week & 18 & 19 \\
\hline$>10$ pints per week & 10 & 5 \\
\hline \multicolumn{3}{|l|}{ Recent anti-inflammatory drug } \\
\hline therapy & 7 & 12 \\
\hline \multicolumn{3}{|l|}{ No. of patients with hospital } \\
\hline \multicolumn{3}{|l|}{ Duration of hospital admission } \\
\hline$<1$ week & 13 & 11 \\
\hline $1-2$ weeks & 2 & 5 \\
\hline 3 weeks + & 1 & 1 \\
\hline \multicolumn{3}{|l|}{ Reason for hospital admission } \\
\hline Bleeding & 12 & 12 \\
\hline Abdominal pain & 3 & 3 \\
\hline Other & 1 & 2 \\
\hline \multicolumn{3}{|l|}{ Ulcer size } \\
\hline Small $(<1 \mathrm{~cm})$ & 12 & 8 \\
\hline Medium $(1-2 \mathrm{~cm})$ & 23 & 30 \\
\hline Large $(2 \mathrm{~cm}+)$ & 15 & 12 \\
\hline \multicolumn{3}{|l|}{ Ulcer site } \\
\hline Antrum & 10 & 8 \\
\hline Incisura & 6 & 3 \\
\hline Body & 24 & 29 \\
\hline High lesser curve/fundus & 10 & 10 \\
\hline Multiple ulcers & 6 & 3 \\
\hline
\end{tabular}


Table 2 Results of treatment: healing

\begin{tabular}{|c|c|c|c|}
\hline \multirow{2}{*}{$\begin{array}{l}\text { Treatment } \\
\text { group }\end{array}$} & \multicolumn{2}{|c|}{$\begin{array}{l}\text { No. with } \\
\text { healed ulcers at }\end{array}$} & \multirow{2}{*}{$\begin{array}{l}\text { Not healed } \\
\text { at } 12 \text { weeks }\end{array}$} \\
\hline & 6 weeks & 12 weeks & \\
\hline Caved-S (50) & $30(60 \%)$ & $44(88 \%)$ & $6(12 \%)$ \\
\hline Cimetidine (50) & $33(66 \%)$ & $47(94 \%)$ & $3(6 \%)$ \\
\hline
\end{tabular}

-2 , and severe -3 . The maximum weekly pain score is therefore 21 for day pain and 21 for night pain. The range of symptoms was so wide (day pain score - Caved-S average $8 \cdot 65$, standard deviation $\pm 7 \cdot 10$, cimetidine average $10 \cdot 04$, standard deviation $\pm 7 \cdot 38$ ) that only those patients with initially moderate or severe symptoms (pain score over 10) have been analysed. The pre-treatment pain scores for the two groups were similar. There was then a fairly rapid decline in pain ratings, levelling off over the last two weeks to approximately the same level for both groups (Fig. 1). The statistical comparison between the two treatment groups was therefore confined to weeks 0,1 , and 2 . The rate of decline in pain ratings was expressed as a linear function by logarithmic transformation. Although cimetidine appears to be more effective than Caved-S in relieving symptoms this difference did not reach a significant value for day pain. There is, however, clear evidence that cimetidine (over the first two weeks of administration) reduces night pain more quickly than Caved-S.

Nineteen of the 100 patients in the study were on anti-inflammatory drug therapy before diagnosis (aspirin, seven; benorylate, one; indomethacin
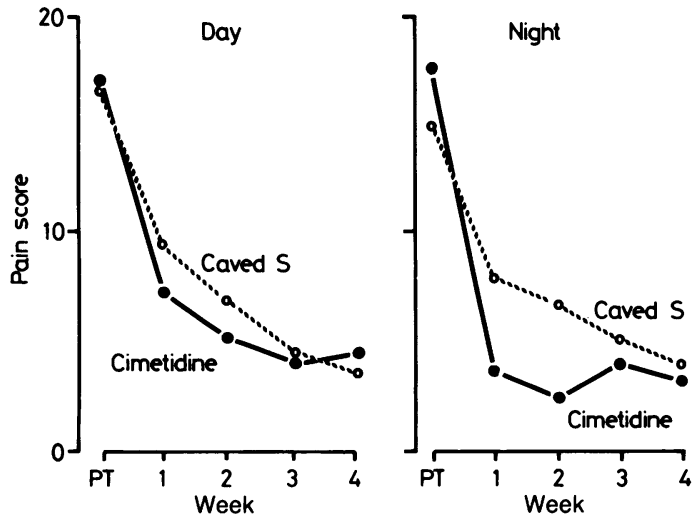

Fig. 1 Pain score before and during treatment. Note cimetidine is more quickly effective for night pain (only those patients with initially moderate or severe symptoms (pain score over 10) have been analysed). (oral), three (slow release), one (suppository), one; diclofenac sodium, one; flurbiprofen, two; piroxicam, one; prednisone, four). Such drug therapy was more common in those patients over the age of 60 years (25\% compared with $9 \%$; $0.05>p>0.02$ ). It also resulted in a greater proportion of large ulcers (47\% compared with $22 \%$ for those patients not on drug treatment; $0.05>p>0.02$ ); and increased the acute admission rate for gastrointestinal bleeding ( $78 \%$ compared with $17 \%$; $<<0.001$ ).

In nine patients ulcer healing was not achieved after 12 weeks' treatment. Seven patients had a further six weeks' drug therapy and in only one patient was ulcer healing achieved. Eight of these nine patients came to gastric surgery and there was no mortality (Table 3).

The rate of ulcer healing was not influenced by the patients' age, sex, smoking or drinking habit, duration of ulcer disease, period of inpatient therapy, recent anti-inflammatory drug therapy, or ulcer size or site.

\section{RESULTS OF MAINTENANCE THERAPY}

As 56 patients have completed one or more years' treatment, a preliminary analysis of the results is shown in Fig. 2. Twenty-eight patients have been treated with Caved-S and 28 with cimetidine for one year. There have been four ulcer recurrences in each subgroup (14\%) within the first six months. No attempt has been made to analyse in detail the results of the second year of maintenance treatment but there are further ulcer recurrences (four on Caved-S and five on cimetidine). This is compared with our previous gastric ulcer study which included a two-year follow-up after ulcer healing but without maintenance therapy. ${ }^{2}$ In it we showed an overall recurrence rate of $44 \%$, with most ulcers occurring in the first year $(33 \%)$.

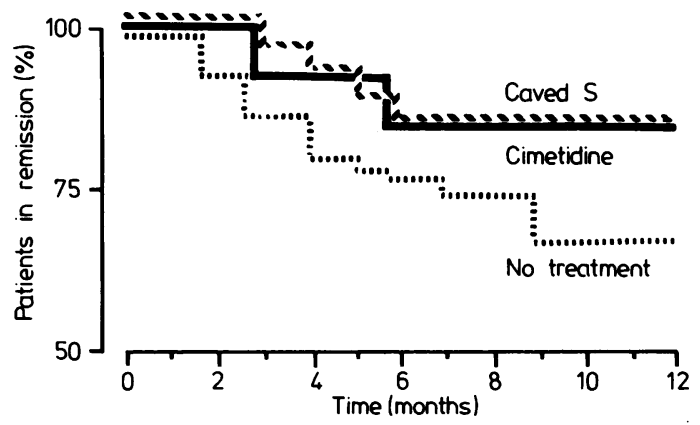

Fig. 2 Results of maintenance therapy for the first year of the present study compared with no treatment in our previous trial (1978). 
Table 3 Outcome of those patients whose ulcers were not healed after 12 weeks of treatment

\begin{tabular}{|c|c|c|c|c|c|c|c|c|}
\hline \multirow[b]{2}{*}{$\begin{array}{l}\text { Time from } \\
\text { initial } \\
\text { endoscopy }\end{array}$} & \multicolumn{3}{|c|}{ Ulcer size at } & \multirow[b]{2}{*}{$\begin{array}{l}\text { Treatment } \\
\text { continued }\end{array}$} & \multicolumn{2}{|c|}{ Ulcer size at } & \multicolumn{2}{|c|}{ Findings at surgery } \\
\hline & $0 / 52$ & $6 / 52$ & $12 / 52$ & & $18 / 52$ & $24 / 52$ & $\begin{array}{l}\text { Week from } \\
\text { initial } \\
\text { endoscopy }\end{array}$ & $\begin{array}{l}\text { Ulcer } \\
\text { size }\end{array}$ \\
\hline \multicolumn{9}{|l|}{$\begin{array}{l}\text { Treatment } \\
\text { group }\end{array}$} \\
\hline Caved-S & $\begin{array}{l}\text { M } \\
\text { M } \\
\text { L } \\
\text { M } \\
\text { M } \\
\text { L }\end{array}$ & $\begin{array}{l}M \\
\text { S } \\
M \\
\text { AH } \\
\text { M } \\
\text { S }\end{array}$ & $\begin{array}{l}\text { M } \\
\text { AH } \\
\text { AH } \\
\text { L } \\
\text { S } \\
\text { M }\end{array}$ & $\begin{array}{l}\text { Caved-S } \\
\text { Cimetidine } \\
\text { Cimetidine } \\
\text { Cimetidine } \\
\text { Cimetidine } \\
\text { Caved-S+ } \\
\text { Cimetidine }\end{array}$ & $\begin{array}{l}\overline{\text { M }} \\
\text { AH } \\
\text { AH } \\
\text { AH } \\
\text { AH }\end{array}$ & $\begin{array}{l}- \\
- \\
\overline{A H} \\
-\end{array}$ & $\begin{array}{l}13 \\
39 \\
28 \\
47 \\
33 \\
20\end{array}$ & $\begin{array}{l}\text { Large } \\
\text { Small } \\
\text { Healed } \\
\text { Healed } \\
\text { Healed } \\
\text { Small }\end{array}$ \\
\hline Cimetidine & $\begin{array}{l}\mathrm{S} \\
\mathrm{L} \\
\mathrm{M}\end{array}$ & $\begin{array}{l}\text { M } \\
\text { L } \\
\text { S }\end{array}$ & $\begin{array}{l}\text { AH } \\
\text { AH } \\
\text { S }\end{array}$ & $\begin{array}{l}\text { Cimetidine } \\
\text { Cimetidine } \\
\text { Cimetidine } \\
\text { +Caved-S }\end{array}$ & $\begin{array}{l}\mathrm{L} \\
\mathrm{H} \\
-\end{array}$ & $\bar{z}$ & $\begin{array}{l}20 \\
\text { No surgery } \\
16\end{array}$ & $\begin{array}{l}\text { Small } \\
\text { Medium }\end{array}$ \\
\hline
\end{tabular}

Ulcer size: $\mathrm{L}=$ large $(2 \mathrm{~cm}+) . M=$ medium $(1-2 \mathrm{~cm}) . S=$ small $(<1 \mathrm{~cm}) . A H=$ almost healed. $\mathrm{H}=$ healed.

\section{Discussion}

HEALING STUDY

The patients included in this study are completely unselected and represent almost the total yield of gastric ulcers presenting to the Department of Radiology and the Endoscopic Unit over a threeyear period. One hundred and seventeen patients were initially entered into the study. Six patients were withdrawn because the initial endoscopic biopsy showed cancer and in a further patient this was picked up by a biopsy taken after six weeks' therapy. The endoscopic appearance taken with the biopsy of an ulcer aids recognition of an ulcer cancer, ${ }^{4}$ and we feel therefore that the treatment period can safely be extended to 12 weeks. The importance, however, of endoscopic biopsy of all gastric ulcers is emphasised by two of our patients who were treated with cimetidine. Their symptoms disappeared and their ulcers healed but biopsies detected carcinoma, later confirmed at laparotomy. These two cases are similar to others in the literature on cimetidine therapy in which both the healing of ulcer cancers and relief of dyspeptic symptoms occurred, ${ }^{5}$ and two others we have met ourselves, which are not in this study.

The true incidence of drug-induced gastric ulcer is still much debated, as the evidence for this association is very slender. ${ }^{6}$ Cooke and Thompson ${ }^{7}$ have recently reviewed the medication taken by 202 patients admitted with gastric ulcer to the Bristol Royal Infirmary between 1974-78, and found that $18 \%$ were on a non-steroidal anti-inflammatory drug
(NSAD). In our study, such drug therapy is also an important contributing factor, as 19 out of the 100 patients were receiving treatment before diagnosis (four on steroids and 15 on NSAD). Fifteen were admitted with acute gastrointestinal bleeding (78\%) but only two patients had later to be withdrawn from the study because of continued bleeding (8\%). This low incidence of continuing bleeding or rebleeding requiring surgical intervention contrasts with other studies that have shown that from $21 \%$ to $42 \%$ come finally to surgery. . $^{-11}$

The healing rate of $66 \%$ after six weeks' cimetidine therapy is in line with the results obtained by previous workers using cimetidine. ${ }^{12-16}$ It is a rather low healing rate compared with the results of duodenal ulcer treatment but it can be improved by a further six weeks' therapy when $94 \%$ of all ulcers are healed. Caved-S produced a slightly lower healing rate $(60 \%$ at six weeks and $88 \%$ at 12 weeks) but this did not reach statistical significance.

Follow-up of the nine patients with ulcers unhealed after 12 weeks' treatment showed that neither continuing nor changing the treatment was very successful in producing further ulcer healing. We therefore recommend that if an ulcer remains unhealed after 12 weeks' treatment the patient should undergo surgery.

Ciclitera in $1977^{17}$ showed that cimetidine was more effective than placebo in relieving the pain associated with gastric ulceration. In this study the level of symptoms in the two treatment groups was evenly matched for both day and night pain in the 
pre-treatment week. After treatment began there was a rapid decline in pain scores of both day and night pain. In the first two weeks cimetidine caused the night pain score to fall more rapidly than did Caved-S. This may be explained by the fact that the last dose of cimetidine is given just before retiring and Caved-S was not given at night. There was no other statistical difference between the two drugs.

No clinically significant side-effects were encountered, although safety screening picked up two transient rises in liver enzymes in patients on cimetidine, these settled without having to discontinue therapy. In any long-term drug therapy, it is important to look for possible side-effects from chronic ingestion of the drug. Caved-S used to contain, as well as deglycyrrhizinated liquorice and a mixture of antacids, bismuth subitrate (withdrawn in 1980).

In both France and Australia, encephalopathy has been reported as a complication of taking large doses of bismuth salts ( 5 to $25 \mathrm{~g}$ per day). ${ }^{18}{ }^{19}$ The total daily dose in this study is $400 \mathrm{mg}$ and at this dosage no clinical trial worker has encountered any such problems.

It has been debated for some time whether long-term cimetidine therapy may result in an increased risk of gastric cancer. ${ }^{20}$ This could occur by the conversion within the stomach of cimetidine into a nitrozo derivative, but long-term animal studies have shown no such malignant potential. Likewise, the hypochlorhydria produced by cimetidine could result in bacterial colonisation and intragastric formation of $\mathrm{N}$-nitrosoma compounds which are known to be carcinogenic. It has, however, been shown that sustained bacterial colonisation rarely occurs during maintenance cimetidine therapy and that the levels of nitrate in gastric juice are rarely raised. ${ }^{21}$ Any possible longterm risks of drug therapy must also be balanced against the knowledge that a partial gastrectomy has a very definite mortality in those older patients with gastric ulcers, and that a partial gastrectomy itself increases the risk of gastric cancer. ${ }^{22}$

The effectiveness of Caved-S in the treatment of gastric ulceration as shown in this study confirms the results obtained in our previous trial. ${ }^{2}$ This, however, contrasts with the trial published by Bardhan $e a^{23}$ in which they compared Ulcedal with placebo and could find no difference in the rate of gastric ulcer healing. They therefore concluded that 'deglycyrrhizinated liquorice has no continuing place in clinical practice'. These conflicting results are, at first sight, difficult to understand, as both Ulcedal and Caved-S contains deglycyrrhizinated liquorice (DGL) prepared by the same manufacturer. In Ulcedal the liquorice is then packed in a gelatin capsule and is swallowed whole, whereas in Caved-S it has to be chewed. We believe that it is this difference in formulation that has produced these conflicting results. Although the gelatin capsule does disintegrate within the stomach, the liquorice does not break up and disperse, but passes through intact into the small bowel.

To achieve gastric ulcer healing the liquorice must be partly released within the stomach and absorbed through the gastric mucosa. ${ }^{24}$ The liquorice in Ulcedal would appear to be released and presumably absorbed lower down in the gastrointestinal tract. Deglycyrrhizinated liquorice has been shown in animals to protect the gastric mucosa from the damaging effect of both aspirin and bile. ${ }^{25-27}$ If, however, deglycyrrhizinated liquorice and cimetidine are used together, the combination is more effective in reducing aspirin-induced mucosal damage than either drug used alone. ${ }^{28}$

In this study we have confirmed that Caved-S is as effective as cimetidine in gastric ulcer therapy. We therefore suggest that the combination of a histamine $\mathrm{H}_{2}$ antagonist and Caved-S should be tried to see if the rate of gastric ulcer healing can be further accelerated.

\section{MAINTENANCE STUDY}

That gastric ulcers tend to recur rapidly after healing is well documented. ${ }^{29}{ }^{30}$ So far, in the present study 28 patients in each subgroup have completed one year or more of maintenance treatment, and there had been four ulcer recurrences during the first year in each subgroup (14\%).

Maintenance treatment with either Caved-S or cimetidine does not appear to reduce the incidence of early relapse (first six months), but is more successful in reducing late recurrences (six to 12 months) (Fig. 2). It would be interesting to see if this early relapse could be reduced by continuing the full initial dosage for a further six weeks or so after healing is endoscopically complete.

The overall recurrence rate is similar to the two English studies of cimetidine versus placebo so far published, in which $800 \mathrm{mg}$ and $1 \mathrm{~g}$ of cimetidine per day were used. ${ }^{31}{ }^{32}$ Slightly better results have been obtained in studies from Denmark and Australia ${ }^{33-}$

${ }^{35}$ but the number of patients in each treatment group of all the studies is rather small.

In the second year of our maintenance treatment, there have been nine further ulcer recurrences, giving a total recurrence rate of $30 \%$. As this second year's follow-up is still incomplete, the final figure may be even higher. Single drug therapy appears, therefore, to delay rather than prevent gastric ulcer recurrence. 
The authors wish to thank their colleagues for allowing them to take over the clinical management of their patients with gastric ulceration.

\section{References}

1 Anonymous. Cimetidine now. Lancet 1981; 1: 875-7.

2 Morgan AG, McAdam WAF, Pacsoo C, Walker BE, Simmons AV. Cimetidine: an advance in gastric ulcer treatment? Br Med J 1978; 2: 1323-6.

3 Davies GJ, Rhodes J, Calcraft BJ. Complications of carbenoxolone therapy. Br Med J 1974; 3: 400-2.

4 Mountford RA, Brown P, Salmon PR, Alvarenga C, Neumann CS, Read AE. Gastric cancer detection in gastric ulcer disease. Gut 1980; 21: 9-17.

5 Taylor RH, Menzies-Gow N, Lovell D, La Brooy SJ, Misiewicz JJ. Misleading response of malignant gastric ulcers to cimetidine. Lancet $1978 ; 1: 686-7$.

6 Milton-Thompson GJ. The pathophysiology of the gastric mucosa with special reference to the natural history and treatment of gastric ulcer. In: Wastell C, Lance P, eds. Cimetidine. The Westminster Hospital Symposium. Edinburgh: Churchill Livingstone, 1978: 249-57.

7 Cooke P, Thompson MR. Old ladies, drugs and gastric ulceration. Gut 1981; 22: A430.

8 Birnie GG, Kennedy F, Mackay C, Watkinson G. Experience of an upper gastrointestinal bleeding management team. Gut 1981; 22: A416.

9 Jones PF, Johnston SJ, McEwan AB, Kyle J, Needham CD. Further haemorrhage after admission to hospital for gastrointestinal haemorrhage. $\mathrm{Br} \mathrm{Med} J$ 1973; 3: $660-4$.

10 Schiller KFR, Truelove SC, Williams DG. Haematemasis and melaena, with special reference to factors influencing the outcome. Br Med J 1970; 2: 7-14.

11 Hunt PS, Hansky J, Korman MG. Mortality in patients with haematemasis and melaena: a prospective study. Br Med J 1979; 1: 1238-40.

12 Frost F, Rahbek I, Rune SJ et al. Cimetidine in patients with gastric ulcer: a multicentre controlled trial. $\mathrm{Br}$ Med J 1977; 2: 795-9.

13 Tanner AR, Cowlishaw JL, Cowen AE, Ward M. Efficacy of cimetidine and tri-potassium di-citrato bismuthate (De-nol) in chronic gastric ulceration Med J Aust 1979; 1: 1-2.

14 Porro BG, Petrillo M. Short and long-term treatment of gastric ulcer: a controlled trial comparing cimetidine and carbenoxolone sodium. In: Dresse $\mathrm{A}$ et al, eds. Second national symposium on cimetidine. Brussels, Oct 27, 1979. Amsterdam: Excerpta Medica, 1980: 161-70.

15 Bader JP, Morin T, Bernier JJ et al. Treatment of gastric ulcer by cimetidine. A multicentre trial. In: Burland WL, Simkins MA, eds. Cimetidine: Proceedings of the second international symposium on histamine $\mathrm{H}_{2}$ receptor antagonists. Amsterdam: Excerpta Medica, 1977: 287-97.

16 Smith PM, Edwards JL, Aubrey DA. Gastric secretory studies and cimetidine treatment in gastric ulcers. In: Wastell C, Lance P, eds. Cimetidine: the Westminster Hospital symposium. Edinburgh: Churchill Livingstone, 1978: 281-8.

17 Ciclitira J, Machell RJ, Farthing MJG, Dick AP, Hunter JO. Double-blind controlled trial of cimetidine in the healing of gastric ulcer. Gut 1979; 20: 730-4.

18 Murray JR. Bismuth neurotoxicity. Med J Aust 1978; 1: 279-80.

19 Supino-Viterbo $\mathrm{V}$ et al. Toxin encephalopathy due to ingestion of bismuth salts: clinical and EEG studies of 45 patients. J Neurol Neurosurg Psychiat 1977; 40: 748-52.

20 Anonymous. Does cimetidine cause gastric cancer? $\mathrm{Br}$ Med J 1981; 1: 1178-9.

21 Muscroft TJ, Youngs Denise J, Burdon DW, Keighley MRB. Cimetidine is unlikely to increase formation of intragastric $\mathbf{N}$-Nitroso-compounds in patients taking a normal diet. Lancet 1981; 1: 408-10.

22 Anonymous. After gastrectomy. $\mathrm{Br} \mathrm{Med} J$ 1981; 1: 1096/7.

23 Bardhan KD, Cumberland DC, Dixon RA, Holdsworth CD. Clinical trial of deglycyrrhizinised liquorice in gastric ulcer. Gut 1978; 19: 779-82.

24 Symons AM, Parke DV. The effects of sodium carbenoxolone on the stability of cellular membranes. Scand J Gastroenterol 1980; suppl. XI: 3-10.

25 Rees WDW, Rhodes J, Wright JE, Stamford IF, Bennett A. Effect of deglycyrrhizinated liquorice on gastric mucosal damage by aspirin. Scand J Gastroenterol 1979; 14: 605-7.

26 Morgan RJ, Nelson LM, Russell RI, Plevin T. The effect of deglycyrrhinized liquorice (DGL) on the occurrence of aspirin-induced gastric lesions and the absorption of aspirin (ASA) in rats. Scott Med J 1981; 26: 87 .

27 Morris TJ, Calcraft BJ, Rhodes J, Hole D, Morton MS. Effect of deglycyrrhizinated liquorice compound on the gastric mucosal barrier of the dog. Digestion 1974; 11: 355-63.

28 Bennet A, Clark-Wibberley T, Stamford IF, Wright JE. Aspirin-induced mucosal damage in rats: cimetidine and deglycyrrhizinated liquorice together give greater protection than low doses of either drug alone. J Pharm Pharmacol 1980; 32: 151.

29 Piper DW, Greig M, Coupland GAE, Hobbin E, Shinners J. Factors relevant to the prognosis of chronic gastric ulcer. Gut 1975; 16: 714-8.

30 Hanscom DH, Buchman E. The follow-up period. Gastroenterology 1971; 61: 585-91.

31 Machell RJ, Ciclitira PJ, Farthing MJG, Dick AP, Hunter JO. Cimetidine in the prevention of gastric ulcer relapse. Postgrad Med J 1979; 55: 393-5.

32 La Brooy SJ, Taylor RH, Ayrton C et al. Cimetidine in the maintenance treatment of gastric ulceration. Hepatogastroenterology (Suppl) XI. Int. Congr. Gastroenterol. Hamburg, 1980: 205.

33 Birger Jensen K, Mollman KM, Rahbek KM, Rask Madsen J, Rune SJ, Wulf HR. Prophylactic effect of 
cimetidine in gastric ulcer patients. Scand $J$ Gastroenterol 1979; 14: 175-6.

34 Kang JY, Canales J, Piper DW. The use of long-term cimetidine in the prevention of gastric ulcer relapse double blind trial. Annual Scientific Meeting Gastroenterology Society of Australia, Brisbane, May 14-15,
1979. A9.

35 Wulff HR, Rune SJ. A comparison of studies on the treatment of gastric ulceration with cimetidine. In: Wastell C, Lance P, eds. Cimetidine: the Westminster Hospital symposium. Edinburgh: Churchill Livingstone, 1978: 281-8. 